\title{
Ornamental plants for floating treatment wetlands: Preliminary results
}

\author{
Alberto Barco, Maurizio Borin \\ Department of Agronomy, Food, Natural Resources, Animals and Environment (DAFNAE), University of \\ Padova, Agripolis Campus, Legnaro (PD), Italy
}

\begin{abstract}
Floating treatment wetlands (FTWs) represent a novel ecotechnology for the treatment of different types of wastewaters in natural or artificial water bodies, through the use of traditional rooted emergent macrophyte species supported by floating rafts. Although many studies have reported the treatment performances of FTWs, showing an excellent aptitude for removing nutrients, heavy metals as well as suspended solids, the investigation of vegetation has not received much attention up to now, especially for herbaceous ornamental plant species that could form an interesting opportunity to improve water quality and the esthetic-ornamental value of urban water bodies. For this reason, a pilot scale FTW was installed in Northern Italy to assess the growth performances of eleven wetland species having ornamental features: Canna indica L., Pontederia cordata L., Thalia dealbata Fraser ex Roscoe, Acorus calamus L., Juncus effusus L., Iris laevigata L., Mentha aquatica L., Oenanthe javanica (Blume) DC., Caltha palustris L., Sparganium erectum L. and Zantedeschia aetiopica (L.) Srengel. For these species, a suitability index was elaborated that considers plant survivability, above-mat biomass production, nitrogen uptake, root length and root-shoot ratio. On this basis, the
\end{abstract}

Correspondence: Alberto Barco, Department of Agronomy, Food, Natural Resources, Animals and Environment (DAFNAE), University of Padova, Agripolis Campus, viale dell'Università 16, 35020 Legnaro (PD), Italy.

E-mail: albertobarco92@gmail.com

Key words: Ornamental plants; artificial floating islands; biomass production; root-shoot ratio; nitrogen uptake; plant survival; suitability index.

Acknowledgements: Research conducted with the financial support of MIPAF OIGA 2009 Project Reproduction, cultivation and evaluation of vegetal species for environmental purposes and the contribution of P.A.N. Spinoff of the University of Padova.

Received for publication: 1 February 2020,

Revision received: 14 March 2020.

Accepted for publication: 28 March 2020.

${ }^{\circ}$ Copyright: the Author(s), 2020

Licensee PAGEPress, Italy

Italian Journal of Agronomy 2020; 15:1602

doi:10.4081/ija.2020.1602

This article is distributed under the terms of the Creative Commons Attribution Noncommercial License (by-nc 4.0) which permits any noncommercial use, distribution, and reproduction in any medium, provided the original author(s) and source are credited. results obtained clearly indicated that $C$. indica, P. cordata and $T$. dealbata were the most suitable species for FTW due to their high vigor and colonization of the floating mats $\left(1638.9 \mathrm{~g} \mathrm{~m}^{-2}, 483.4 \mathrm{~g}\right.$ $\mathrm{m}^{-2}, 566.1 \mathrm{~g} \mathrm{~m}^{-2}$ of above-mat dry biomass, respectively; $38.8 \mathrm{~cm}$, $62.0 \mathrm{~cm}, 43.8 \mathrm{~cm}$ root length, respectively; $0.8,0.9,1.2$ root-shoot ratio, respectively), survival (100\%), nitrogen uptake $\left(15.1 \mathrm{~g} \mathrm{~m}^{-2}\right.$, $15.0 \mathrm{~g} \mathrm{~m}^{-2}, 15.7 \mathrm{~g} \mathrm{~m}^{-2}$ respectively). On the contrary, A. calamus, $S$. erectum and $Z$. aetiopica did not present adequate features for use in FTWs.

\section{Introduction}

Floating treatment wetlands (FTWs) represent a recent alternative within free water surface constructed wetlands, able to treat a large volume of wastewater in already existing natural or artificial water bodies (De Stefani et al., 2011; Faulwetter et al., 2011; Mietto et al., 2013; Chang et al., 2013; Borne, 2014; Borne et al., 2014; Barco and Borin, 2017; Pappalardo et al., 2017; Tharp et al., 2019). This novel approach in the field of wastewater treatment consists of the use of self-buoyant platforms on which the traditional un-floating rooted macrophyte species are installed, and expand their root systems directly in the water column (Hedley and Tanner, 2006).

FTWs have been used to treat different wastewaters, such as those collected from urban districts (Van de Moortel et al., 2010; Chua et al., 2012; Mietto et al., 2013; Duan et al., 2016; Barco and Borin, 2017), eutrophic water (Hu et al., 2010; Quing et al., 2016; Li and Guo, 2017; Olguin et al., 2017), river (Zhou and Wang, 2010; De Stefani et al., 2011; Zhu et al., 2011; Duan et al., 2016; Saeed et al., 2016; Pappalardo et al., 2017; Gao et al., 2017; Dal Ferro et al., 2018; Shahid et al., 2018), stormwater run-off (Ladislas et al., 2015; Lynch et al., 2015; Hartshorn et al., 2016; Ge et al., 2016; McAndrew et al., 2016; Urakawa et al., 2017; Zanin et al., 2018) and agricultural run-off (Spangler et al., 2019).

Interesting performances have been obtained in term of nutrients, organic matter and suspended solids removal rates, as previously reviewed by Chen et al. (2016), Bi et al. (2019) and Rehman et al. (2019). The correct selection of vegetation provides different functions: root filtering effect against suspended solids, oxygen transferal through aerenchym from aerial tissues to root system, absorption of nutrients and heavy metals, surface for microbial biofilm growth, releasing of antimicrobic compounds, phytochelatins and phytometallopores and rhizodeposition products (Vymazal, 2013).

Although different plant species belonging to several botanical families (Poaceae, Typhaceae and Cyperaceae) have been adopted in many FTWs built all over the world, the choice mainly regards a restricted group of un-floating rooted emergent aerenchymatous macrophytes characterized by an excellent capability to survive under hydroponic conditions (Carex spp., 
Phragmites australis, Typha latifolia), even at high pollutants loads (Ibrahim et al., 2017; Rehman et al., 2019). More recently, FTWs have been installed with the double aim of ameliorating the physic-chemical quality of water bodies and the necessity to improve their esthetic-ornamental values, especially in urban settings (Zanin et al., 2018). This latter requirement could be achieved in different ways, such as: i) the selection of species characterized by abundant and colorful flowering; ii) a mixture of different species with variously colored flowers, perhaps with different blooming times; iii) the use of species with aesthetic foliage characteristics (e.g. shape, color, colored and evident veins, mottling), or, iv) transplanting species that maintain a green coverage of floating mats throughout the year (Figure 1). In this scenario, different dual-purpose species (water purification and ornamental value) have been used in FTWs. The most frequent study cases came from China, USA and Italy and investigated the growth of Iris spp., Carex spp., Oenanthe spp., Canna spp. and Pontederia cordata (Figure 2). Focusing attention on I. pseudacorus, KeizerVelk et al. (2014) harvested more than $1071 \mathrm{~g} \mathrm{~m}^{-2}$ of above-mat

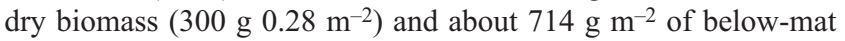
dry biomass (200 g d.m. $0.28 \mathrm{~m}^{-2}$ ) in a commercial nutrient solution. Pavan et al. (2015) reached less than $200 \mathrm{~g} \mathrm{~m}^{-2}$ dry matter (d.m.) and about $500 \mathrm{~g} \mathrm{~m}^{-2} \mathrm{~d} . \mathrm{m}$. of above-mat biomass after the first and second growing seasons, respectively, treating diluted digestate liquid fraction, whereas Barco and Borin (2017) reported excellent biomass production in municipal wastewater with $3700 \mathrm{~g}$ $\mathrm{m}^{-2}$ of above-mat dry biomass (shoot height $135.9 \mathrm{~cm}$ ) and 20200 $\mathrm{g} \mathrm{m}^{-2}$ of below-mat d.m. (root length $46.3 \mathrm{~cm}$ ). Pappalardo et al. (2017) obtained the worst results treating agricultural run-off with $20.2 \mathrm{~g} \mathrm{~m}^{-2}$ of above-mat dry biomass (shoot height $38.4 \mathrm{~cm}$ ) and $86.7 \mathrm{~g} \mathrm{~m}^{-2}$ of below-mat d.m. (root length $76.4 \mathrm{~cm}$ ), due to a very low nutrients concentration in the water.

Wang et al. (2015) tested the growth performances of $P$. corda$t a$ in an urban retention pond, where they harvested about $2.3 \mathrm{~g}$ plant $^{-1}$ of above-mat d.m. and more than 7.5 g plant $^{-1}$ of belowmat d.m. and measured maximum shoot height and root length of about $44 \mathrm{~cm}$ and $43 \mathrm{~cm}$, respectively. Tharp et al. (2019) working in a stormwater retention pond obtained less than $10 \mathrm{~g} \mathrm{plant}^{-1}$ of above-mat d.m. and measured a maximum root length lower than $15 \mathrm{~cm}$. Zhao et al. (2012) cultivated the species in an FTW to ameliorate eutrophic river water and obtained less than $1500 \mathrm{~g} \mathrm{~m}^{-2}$ of above-mat d.m. The growth of Canna was tested: i) in eutrophic river water where the species produced more than $1500 \mathrm{~g} \mathrm{~m}^{-2}$ of above-mat d.m. (Zhao et al., 2012); ii) in stormwater run-off wastewater where it reached a maximum root expansion in the water column of 25-50 cm (White and Cousins, 2013); and iii) in synthetic wastewater where the total length of plants ranged between $54.4 \mathrm{~cm}$ (about $40.6 \mathrm{~cm}$ of shoot height and $13.8 \mathrm{~cm}$ of root length) and $80.7 \mathrm{~cm}$ (about $58.7 \mathrm{~cm}$ of shoot height and $22 \mathrm{~cm}$ of root length) (Zhang et al., 2018).

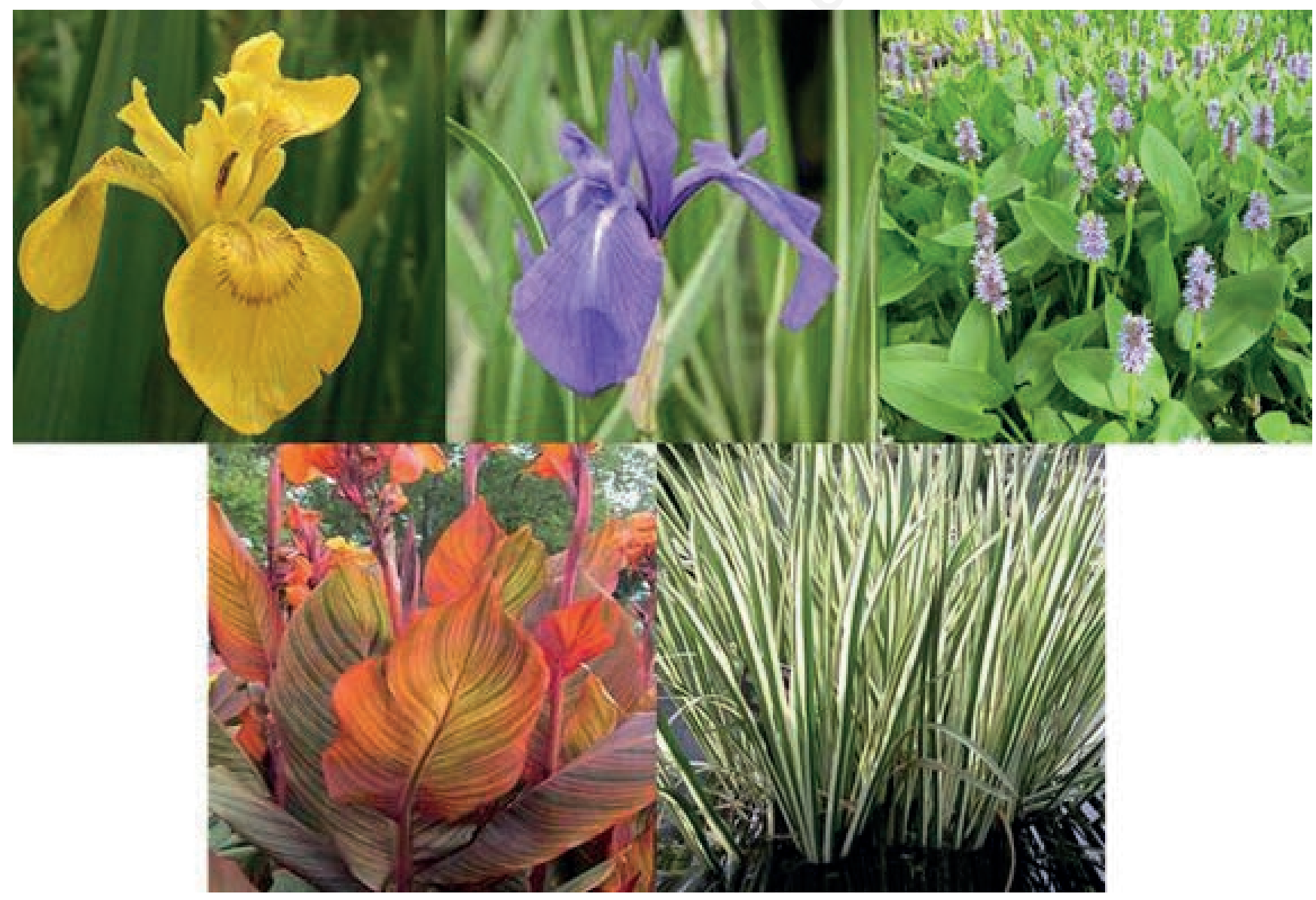

Figure 1. Examples of ornamental plant species usually used in floating treatment wetlands, characterized by: i) colored flowers (top, from left, Iris pseudacorus, Iris laevigata and Pontederia cordata); ii) foliage aesthetic value (bottom, from left, Canna indica and Acorus calamus). 
The performances of different species of the Carex genus were mainly assessed in stormwater run-off. Above-mat d.m. amounted to 71.7-191 g plant ${ }^{-1}$ for C. stricta (Winston et al., 2013) and 93$113 \mathrm{~g} \mathrm{plant}^{-1}$ for C. riparia (Ladislas et al., 2013). Similarly, below-mat d.m. ranged from 86-115 $\mathrm{g} \mathrm{plant}^{-1}$ for C. riparia (Ladislas et al., 2013) to 194.7-220.5 g plant ${ }^{-1}$ (root length $75 \mathrm{~cm}$ ) for $C$. virgata (Winston et al., 2013). The behavior of C. elata was tested in Northern Italy, where it produced 266.9-565.7 $\mathrm{g} \mathrm{m}^{-2}$ of above-mat d.m. (45.7-52.1 cm shoot height) and 166.2-442.6 $\mathrm{g} \mathrm{m}^{-2}$ (66.2-64.8 cm root depth) of below-mat d.m. (Pappalardo et al., 2017).

The adaptability of $O$. javanica was evaluated in FTWs installed to treat river water. In this case, the biomass produced showed a wide fluctuation among trials with minimum values of $96.8 \mathrm{~g} \mathrm{~m}^{-2}$ and $66.8 \mathrm{~g} \mathrm{~m}^{-2}$ of above- and below-mat d.m., respectively (Zhu et al., 2011) and maximum values of $808 \mathrm{~g} \mathrm{~m}^{-2}$ and $677.5 \mathrm{~g} \mathrm{~m}^{-2}$ of above- and below-mat d.m., respectively (Zhou and Wang, 2010).

Given this state of the art, to the best of our knowledge, no other studies have reported the growth performances of more than 4 ornamental species within the same FTW installation. For this reason, the current paper aimed to assess the growth parameters (shoot height, root length, above-mat biomass production) as well as the survivability of eleven different wetland species with ornamental value, installed in a pilot scale FTW in Northern Italy.

\section{Materials and methods}

\section{Experiment description}

The experiment was conducted at the Lucio Toniolo Experimental Farm of the University of Padova, Veneto Region, North-eastern Italy (Lat. $45^{\circ} 11^{\prime} \mathrm{N}, 11^{\circ} 21^{\prime} \mathrm{E}$ ) between December 2009 and July 2010. The experimental site consisted of a north-south orientated greenhouse facility ( $25 \mathrm{~m}$ length, $12 \mathrm{~m}$ width, $6 \mathrm{~m}$ height) covered with a transparent polyethylene plastic film, in which a pilot FTW was installed. The constructed FTW was composed of 3 identical waterproofed polyethylene basins (Fito $\operatorname{Star}($ ) (3 replications) ( $2.5 \mathrm{~m}$ length, $2.0 \mathrm{~m}$ width, $0.6 \mathrm{~m}$ height, volume $3 \mathrm{~m}^{3}$ each). The upper part of each basin was provided with a PN10 PVC plastic pipe (50 mm external diameter) connected with an electro-valve and flow-meter to provide and measure the tap water load, while a PN16 PVC plastic valve (50 mm diameter) was installed in the bottom to allow basin discharge. Each basin surface was covered by 9 Tech-IA floating mats, for a total of 27 floating mats in the experiment. A Tech-IA ${ }^{\circledR}$ floating mat is made of ethylene vinyl acetate (EVA), a recyclable and non-toxic material, with high mechanical, chemical, biological and weather resistance (De Stefani et al., 2011). Each Tech-IA ${ }^{\circledR}$ floating element is rectangular in shape $(45 \times 93$ $\mathrm{cm})$, with eight $(15 \times 15 \mathrm{~cm})$ quadrangular grids for anchoring plants. It weighs $1.7 \mathrm{~kg}$ and supports more than $20 \mathrm{~kg}$ weight.

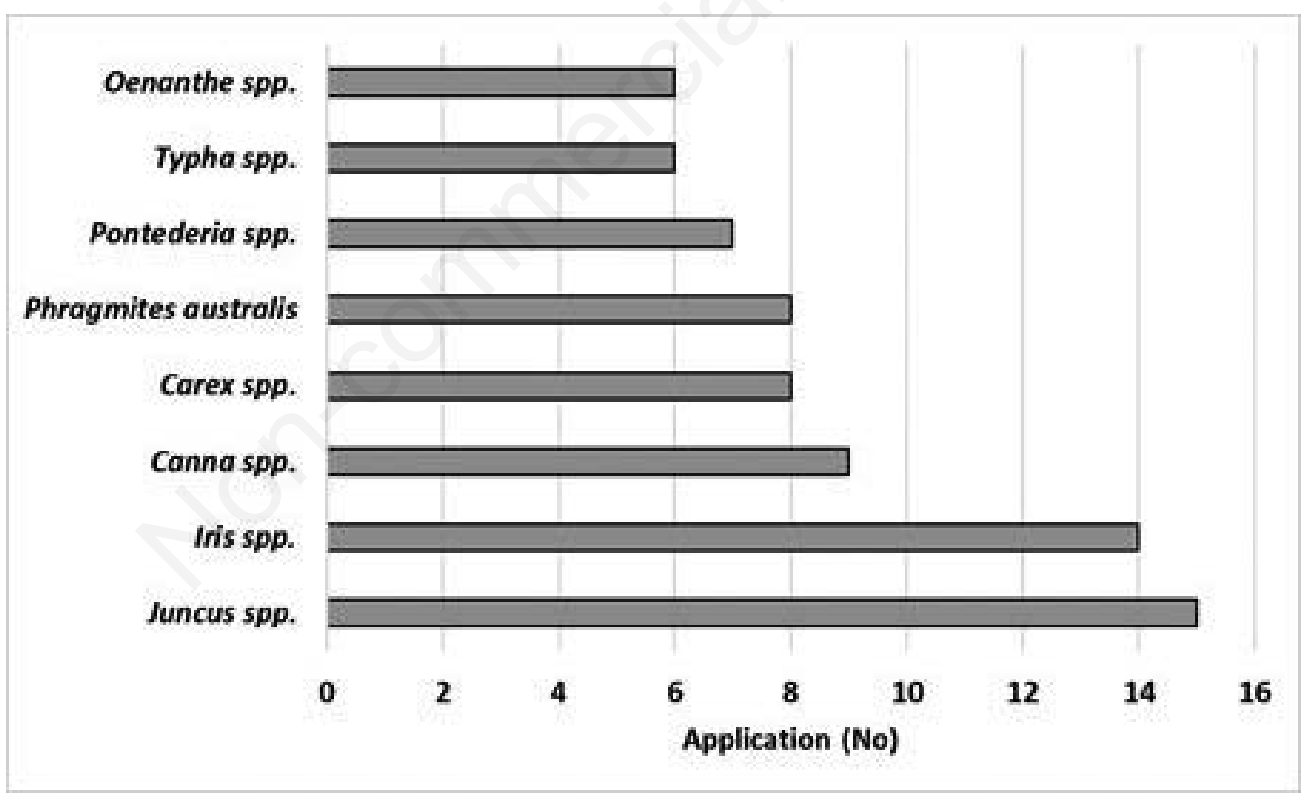

Figure 2. Number of applications of the main dual-purpose wetland species (ornamental value and wastewater treatment) around the world. Iris spp: De Stefani (2012), Mietto et al. (2013), Pavan et al. (2015), Hartshorn et al. (2016), McAndrew et al. (2016), Quing et al. (2016), Barco and Borin (2017), Gao et al. (2017), McAndrew et al. (2017), Pappalardo et al. (2017), Wang et al., (2017), West et al. (2017), Zanin et al. (2018), Sapngler et al. (2019 b). Oenanthe spp.: Zhou and Wang (2010), Hu et al. (2010), Zhu et al. (2011), Duan et al. (2016), Geng et al. (2017), Zanin et al. (2018). Canna spp: Zhang et al. (2014), Ge et al. (2016), Hartshorn et al. (2016), Quing et al. (2016), Saeed et al. (2016), Urakawa et al., (2017), Zanin et al. (2018), Zhang et al. (2018), Spangler et al. (2019 b). Juncus spp.: De Stefani et al. (2011), Ladislas et al. (2013), Ladislas et al. (2015), Lu et al. (2015), Lynch et al. (2015), Pavan et al. (2015), Hartshorn et al. (2016), McAndrew et al. (2016), McAndrew and Ahn (2017), Pappalardo et al. (2017), Urakawa et al. (2017), West et al. (2017), Chanc et al. (2019), Spangler et al. (2019 a), Tharp et al. (2019). Carex spp.: De Stefani et al. (2011), Ladislas et al. (2013), Ladislas et al. (2015), Mc Andrew et al. (2016), McAndrew and Ahn (2017), Pappalardo et al. (2017), Spangler et al. (2019 b), Tharp et al. (2019). Phragmites australis: De Stefani et al. (2011), De Stefani (2012), Mietto et al. (2013), Pavan et al. (2015), Saeed et al. (2016), Barco and Borin (2017), Li and Guo (2017), Sanicola et al. (2018). Pontederia spp.: Wang et al. (2014), McAndrew et al. (2016), McAndrew and Ahn (2017), Olguin et al. (2017). Chanc et al. (2019), Spangler et al. (2019 a), Tharp et al. (2019). Typha spp.: De Stefani et al. (2011), Chua et al. (2012), De Stefani (2012), Lu et al. (2015), Pavan et al. (2015), Zanin et al. (2018). 
The growth and development of eleven different ornamental species, whose botanical description is reported in Table 1, were studied: Iris laevigata Fisch., Pontederia cordata L., Canna indica L., Thalia dealbata Fraser ex Roscoe, Mentha aquatica L., Juncus effusus L., Zantedeschia aetiopica (L.) Srengel, Sparganium erectum L., Acorus calamus L., Oenanthe javanica (Blume) DC. and Caltha palustris L.

The experiment began in December 2009 with the transplanting of 8 species ( 1 species per floating mat; 1 floating mat per basin remained un-vegetated). At this purpose, P. cordata, C. indica, T. dealbata, I. laevigata, J. effusus, Z. aetiopica and S. erectum were transplanted in the floating mats as pieces of rhizome whereas $M$. aquatica as pieces of stolon (20-25 cm length, 3 living sprouts each) obtained from specialist plant nurseries located near the experimental site (transplanting density 2 plants floating mat $^{-1}, 4$ plants $\mathrm{m}^{-2}$ ). A completely randomized experimental design was adopted in which each studied species was replicated three times.

After transplanting there was a period of adaption in which plants remained in contact with tap water without any fertilizer supply, then after the sprouting phase, two consecutive fertilizer applications were done, the first one on March $17^{\text {th }} 2010$, the second on April $1^{\text {st }} 2010$. For this purpose, a prepared nutrient solution was used and gradually added to each basin until an electrical conductivity of about $1500 \mu \mathrm{S} \mathrm{cm}{ }^{-1}$ was reached. The chemical features of the nutrient solution are the following: $\mathrm{KCl} 1.86 \mathrm{mg} \mathrm{L}^{-1}$; $\mathrm{H}_{3} \mathrm{BO}_{3} 0.77 \mathrm{mg} \mathrm{L}^{-1} ; \mathrm{MnSO}_{4} * \mathrm{H}_{2} \mathrm{O} 0.17 \mathrm{mg} \mathrm{L}^{-1} ; \mathrm{ZnSO}_{4} * 7 \mathrm{H}_{2} \mathrm{O} 0.29$ $\mathrm{mg} \mathrm{L}^{-1} ; \mathrm{CuSO}_{4}{ }^{*} 5 \mathrm{H}_{2} \mathrm{O} 0.06 \mathrm{mg} \mathrm{L}{ }^{-1} ; \mathrm{H}_{2} \mathrm{MoO}_{4}\left(85 \% \mathrm{MoO}_{3}\right) 0.04$ $\mathrm{mg} \mathrm{L}^{-1} ; \mathrm{HNO}_{3} 214 \mathrm{mg} \mathrm{L}{ }^{-1} ; \mathrm{Ca}\left(\mathrm{NO}_{3}\right)_{2} 216 \mathrm{mg} \mathrm{L}{ }^{-1} ; \mathrm{NH}_{4} \mathrm{NO}_{3} 63.6$ $\mathrm{mg} 9 \mathrm{~L}^{-1} ; \mathrm{KH}_{2} \mathrm{PO}_{4} 136 \mathrm{mg} \mathrm{L}^{-1} ; \mathrm{K}_{2} \mathrm{SO}_{4} 118 \mathrm{mg} \mathrm{L}{ }^{-1} ; \mathrm{MgSO}_{4} 24.6 \mathrm{mg}$
$\mathrm{L}^{-1} ; \mathrm{KNO}_{3} 54 \mathrm{mg} \mathrm{L}^{-1}$; FeEDTA (6\%) $7.5 \mathrm{mg} \mathrm{L}^{-1}$.

Due to the fact that at the beginning of the growing season, $Z$. aetiopica and $S$. erectum did not survive, even though repetitive transplantations were performed, they were replaced by $A$. calamus and O. javanica, whereas C. palustris was installed in the unvegetated floating mats. These species were chosen in the same phenological phase of previously installed species and transplanted on April $1^{\text {st }} 2010$ as $30 \mathrm{~cm}$ tall plants (transplanting density 2 plants floating mat $^{-1}, 4$ plants $\mathrm{m}^{-2}$ ).

\section{Monitored parameters}

During the experimental period, water $\mathrm{pH}$, electrical conductivity (EC) (measured at $10 \mathrm{~cm}$ depth) and dissolved oxygen (DO) (recorded at $10 \mathrm{~cm}$ and $50 \mathrm{~cm}$ depths of each basin) were measured in situ once a week using a multiparametric probe (Hach-Lange) according to the standard method (APHA, 1998).

Water and air temperature values were measured once a week using a portable thermometer (Ecomorma s.a.s., FT2300) to assess the environmental conditions which affected plants vegetative cycle.

Water integration was done by adding tap water seven times during the experimental period and water volumes supplied were measured through a flowmeter to assess the water consumed by vegetation evapotranspiration.

Plants biometric characteristics, particularly shoot height $(\mathrm{cm})$ and root length $(\mathrm{cm})$, were measured weekly in each floating mat over the entire experimental period through an extensible meter. Aerial fresh biomass production $\left(\mathrm{g} \mathrm{m}^{-2}\right)$ was determined by harvesting plant biomass in each floating mat. The harvesting of veg-

Table 1. List of ornamental species used in the study and the correspondent botanic description.

\begin{tabular}{|c|c|c|c|}
\hline Species & Family & Origin & Botanic description \\
\hline Acorus calamus L. & Acoraceae & Asia & $\begin{array}{l}\text { 0.5-1.0 m height; linear leaves; light green-yellow flowers. } \\
\text { Propagation: rhizome. Bloom: spring }\end{array}$ \\
\hline Caltha palustris $\mathrm{L}$. & Ranunculaceae & Temperate regions of the Northern Hemisphere & $\begin{array}{l}10-80 \mathrm{~cm} \text { height; thick branching roots; } 2-5 \mathrm{~cm} \text { diameter } \\
\text { yellow flower. Propagation: rhizome. Bloom: early spring-late summer. }\end{array}$ \\
\hline Canna indica $\mathrm{L}$. & Cannaceae & $\begin{array}{l}\text { South America, Central America, southeastern } \\
\text { United States }\end{array}$ & $\begin{array}{l}0.5 \text { - } 2.0 \text { m height; hermaphrodite flowers; decorative leaves and } \\
\text { orange-red flowers; small, globular, black pellet seeds. Propagation: } \\
\text { rhizome. Bloom: summer. }\end{array}$ \\
\hline Iris laevigata Fisch. & Iridaceae & Japan & $\begin{array}{l}90-100 \mathrm{~cm} \text { height, blue, purple or violet flowers with rotund, short, } \\
\text { vertical petals. Propagation: rhizome. Bloom: early spring. }\end{array}$ \\
\hline Juncus effusus L. & Juncaceae & Europe, Asia, Africa, North and South America & $\begin{array}{l}1.5 \mathrm{~m} \text { height, lucid, bright green stems; green-brown inflorescence. } \\
\text { Propagation: rhizome. Bloom: summer. }\end{array}$ \\
\hline Mentha aquatica $\mathrm{L}$. & Lamiaceae & Europe, northwest Africa and southwest Asia & $\begin{array}{l}\text { Fleshy with fibrous roots }(90 \mathrm{~cm}) \text {; ovate to lanceolate leaves; small } \\
\text { pink-purple flowers. Propagation: stolon. Bloom: summer. }\end{array}$ \\
\hline $\begin{array}{l}\text { Oenanthe javanica } \\
\text { (Blume) DC. }\end{array}$ & Apiaceae & East Asia, Australia & $\begin{array}{l}1 \mathrm{~m} \text { height; fibrous roots from all nodes; leaves: aromatic, glabrous, } \\
\text { sheath covering the stem; flowers: } 5 \text { white petals and } 5 \text { stamens. } \\
\text { Propagation: rhizome. Bloom: summer. }\end{array}$ \\
\hline Pontederia cordata $L$. & Pontederiaceae & America & $\begin{array}{l}\text { Aquatic species; lucid leaves; blue-purple flowers. Propagation: } \\
\text { rhizome. Bloom: late spring-early summer. }\end{array}$ \\
\hline $\begin{array}{l}\text { Thalia dealbata } \\
\text { Fraser ex Roscoe }\end{array}$ & Marantaceae & Southern and central United States & $\begin{array}{l}\text { Aquatic plant, } 1.8 \mathrm{~m} \text { height; } \\
\text { leaves: blue-green, ovate to lanceolate; flowers: small, violet. } \\
\text { Propagation: rhizome. Bloom: late summer. }\end{array}$ \\
\hline Sparganium erectum $\mathrm{L}$. & Typhaceae & $\begin{array}{l}\text { Temperate regions of both the } \\
\text { Northern and Southern Hemispheres }\end{array}$ & $\begin{array}{l}\text { Aquatic, emergent stems with aerenchym; strap-like leaves; } \\
\text { flowers: borne in spherical heads, hermaphrodite. Propagation: } \\
\text { rhizome. Bloom: summer. }\end{array}$ \\
\hline $\begin{array}{l}\text { Zantedeschia aethiopica } \\
\text { (L.) Srengel }\end{array}$ & Araceae & Southern Africa & $\begin{array}{l}\text { Herbaceous, evergreen, } 0.6-1 \mathrm{~m} \text { height; leaves: arrow shaped, dark } \\
\text { green; inflorescences: large with a pure white spathe and a yellow } \\
\text { spadix. Propagation: rhizome. Bloom: beginning, till late spring. }\end{array}$ \\
\hline
\end{tabular}


etation was done on July $30^{\text {th }} 2010$, to maximize nitrogen uptake from water through plant above-mat biomass. Dry biomass production $\left(\mathrm{g} \mathrm{m}^{-2}\right)$ was obtained by drying $100 \mathrm{~g}$ fresh tissue samples in a forced air oven at $65^{\circ} \mathrm{C}$ for about 48 hours, until constant weight was reached. Dry biomass was then milled to $2 \mathrm{~mm}$ and analyzed to quantify Total Kjeldhal Nitrogen (TKN) through titration (FAO, 2011). The total nitrogen content in above-mat tissues was obtained as the product between aerial dry biomass production and nitrogen percentage concentration. The root shoot ratio (root length/shoot height) was calculated on plants biometric characteristics in different phenological phases: sprouting (February $3^{\text {rd }}$ 2010-March $16^{\text {th }} 2010$ ), shoot elongation/flowering (March 24 ${ }^{\text {th }}$ 2010-June $3^{\text {rd }} 2010$ ) and flowering-fruit development (June $10^{\text {th }}$ 2010-July $30^{\text {th }} 2010$ ).

Plant survival, computed at harvesting time, was calculated as the ratio between number of living plants before harvesting and the corresponding number at the beginning of the growing season.

Although Silvestri et al. (2017) reported a multi-adaptive framework to select crops in paludicultural cropping systems, mainly basing on crops biological traits, biomass production and quality as well as aptitude to cultivation, no similar methodologies have been found for artificial floating islands. For this reason, a suitability index (SI) was elaborated to describe the capability of ornamental species to survive in FTWs.

It considers: i) plant survival at harvesting time (SR); the low survival of plants, due to scarce or absent capacity of adaptation to live with roots directly in the water column and/or to overcome winter frost, compromises the success of the system; ii) above-mat biomass production $(\mathrm{AB})$ that estimates the potential of plants in removing pollutants; in fact, above-mat biomass can be harvested and consequently nutrients/pollutants can be removed; iii) nitrogen uptake by above-mat biomass (NU), to assess the capacity to remove $\mathrm{N}$ with harvesting; iv) maximum root length (RL), indicating the water column involved in depurative processes; v) average root-shoot ratio $(\mathrm{R} / \mathrm{S})$, to describe the balance between aerial and root organs and therefore, the risk that floating vegetated barriers overturn under wind pressure. This risk is higher in presence of tall plants with reduced root depth.

The variability of data (form minimum to maximum values) within each parameter considered in the SI calculation was divided into three equal classes, as shown in Table 2. An individual score was attributed for each class within each parameter (Table 2): i) from 0 to 2 for plant survivability where 0 (corresponding to plant survivability lower than $33.3 \%$ ) represented the worst condition without any functionality of the FTW, whereas 2 the best ones with the prompt and complete establishment of vegetation; ii) from 1 to 3 for $\mathrm{AB}, \mathrm{NU}, \mathrm{RL}$ and $\mathrm{R} / \mathrm{S}$ where 1 represented the worst whereas 3 the best conditions for the functionality of FTWs.

For all parameters, greater the score, greater the suitability of the species to be adopted in FTWs.

The SI was calculated through the following equation: $\mathrm{SI}=\mathrm{SR}$ $\times(\mathrm{AB}+\mathrm{NU}+\mathrm{RL}+\mathrm{R} / \mathrm{S})$.

\section{Statistical analysis}

The normality of data was checked through the Bartlett statistical test, whereas the homoscedasticity through the Levene test. Collected data followed a normal distribution and the variance is homogeneous. For all studied species except for Z. aetiopica and $S$. erectum that did not survive till the end of the study, maximum plant biometric characteristics (shoot height and root length), above-mat biomass production, nitrogen percentage concentration as well as nitrogen content in above-mat dry biomass were statistically analyzed by one-way analysis of variance test (ANOVA) at
$\mathrm{P}<0.05$ and the differences between average values were detected by least significant difference (LSD) test $(\mathrm{P}<0.05)$. The regression between root length and shoot height was assessed through a simple regression analysis model $(\mathrm{P}<0.05)$.

\section{Results and discussion}

\section{Water monitoring}

During the entire experimental period, water $\mathrm{pH}$ ranged between 6.2 and 8.5 (Figure 3A). The average value of 7.0 was similar to values recorded at the inlet of other FTWs installed in the same area (pH 7.5: Barco and Borin, 2017; $\mathrm{pH} 7.4$; Mietto et al., 2013), and was suitable for the functioning of FTW since the microbial processes of ammonification and nitrification proceed rapidly under this water $\mathrm{pH}$ (optimum $\mathrm{pH}$ for ammonification: 6.58.5, optimum $\mathrm{pH}$ for nitrification 6.6-8.0) (Vymazal and Kropfelova, 2008).

During the monitoring period, water EC irregularly varied between $826.3 \mu \mathrm{S} \mathrm{cm} \mathrm{cm}^{-1}$ and $1489.3 \mu \mathrm{S} \mathrm{cm}^{-1}$, average $1194.7 \mu \mathrm{S}$ $\mathrm{cm}^{-1}$ (Figure 2B). Measured values were always higher than the optimal range for crop irrigation indicated for semi-arid regions by Ayers and Westcot (1994) and Bortolini et al. (2018) (EC lower than $700 \mu \mathrm{S} \mathrm{cm}^{-1}$ ). The highest values were measured from March $11^{\text {th }} 2010$ to April $27^{\text {th }} 2010$ in correspondence to the two fertilization treatments (March 17 2010 and April $1^{\text {st }}$ 2010) (Figure 3B), as already confirmed in similar experimental conditions by West et al. (2017). In the following experimental period, the EC was reduced if compared to the previous period due to: i) the lack of other fertilization treatments; ii) the consequent dilution effect due to nutrients absorption by plant root systems and the increasing of water volumes added to compensate for losses through plant evapotranspiration (Figure 3B).

The DO ranged between $0.4 \mathrm{mg} \mathrm{L}^{-1}$ and $6.1 \mathrm{mg} \mathrm{L}^{-1}$ at $10 \mathrm{~cm}$ depth, and between $0.2 \mathrm{mg} \mathrm{L}^{-1}$ and $6.1 \mathrm{mg} \mathrm{L}^{-1}$ at the bottom of the basins (Figure 3C). In the first part of the experimental period (from February $3^{\text {rd }} 2010$ to April $15^{\text {th }} 2010$ ), the DO concentration did not follow any precise temporal trend, with an irregular fluctuation of values over time. On the contrary, from April $21^{\text {st }} 2010$ to

Table 2. Partition of data variability within the different parameters involved in the calculation of the suitability index.

\begin{tabular}{lccc} 
Parameter & Class & Score & Range \\
Survivability (\%) & 1 & 0 & $<33.3$ \\
& 2 & 1 & $33.3-66.6$ \\
\multirow{2}{*}{ Above-mat biomass production $\left(\mathrm{g} \mathrm{m}^{-2}\right)$} & 1 & 1 & $>66.6$ \\
& 2 & 2 & $1054.0-2108.0$ \\
& 3 & 3 & $>2108.0$ \\
\hline Nitrogen uptake $\left(\mathrm{g} \mathrm{m}^{-2}\right)$ & 1 & 1 & $<10.7$ \\
& 2 & 2 & $10.7-21.4$ \\
Root length (cm) & 3 & 3 & $>21.4$ \\
& 1 & 1 & $<20.7$ \\
& 2 & 2 & $20.7-41.3$ \\
Root/Shoot ratio & 3 & 3 & $>41.3$ \\
& 1 & 1 & $<0.4$ \\
& 2 & 2 & $0.4-0.8$ \\
& 3 & 3 & $>0.8$ \\
\hline
\end{tabular}


July $16^{\text {th }} 2010$, DO concentration fluctuations reduced even though it was not completely stable either at the surface or on the bottom of basins (Figure 3C). Over the entire experimental period, DO concentration measured at the water surface was higher than on the bottom with average values of $2.6 \mathrm{mg} \mathrm{L}^{-1}$ and $2.4 \mathrm{mg} \mathrm{L}^{-1}$, respectively (Figure 3C).

During the experimental period, air and water temperature followed a similar seasonal trend with a progressive increase from the beginning (in February $15.1 \pm 0.2^{\circ} \mathrm{C}$ and $15.4 \pm 0.4^{\circ} \mathrm{C}$ for air and water temperature, respectively) till the end of the study (in July $31.7 \pm 1.2^{\circ} \mathrm{C}$ and $28.6 \pm 1.1^{\circ} \mathrm{C}$ for air and water temperature, respectively) (Figure 4). Monthly air temperatures recorded in the study were always higher than those measured in open-air conditions of the same area (February: $5.0^{\circ} \mathrm{C}$, March: $8.1^{\circ} \mathrm{C}$, April: $13.8^{\circ} \mathrm{C}$, May: $17.7^{\circ} \mathrm{C}$, June: $21.9^{\circ} \mathrm{C}$, July: $24.7^{\circ} \mathrm{C}$ ), probably due to the greenhouse effect. In general, monthly water temperature was almost always lower than air one.

Water consumption by plants evapotranspiration followed the same monthly trend reported for air and water temperature (Figure 4 ). The lowest values were recorded at the beginning of the growing season (February and March, $24.7 \mathrm{~mm}$ on average) in correspondence to the sprouting phase, whereas the highest were obtained in June and July ( $72.3 \mathrm{~mm}$ on average) with the progressive increase of plant size, leaf area and consequent coverage of the floating mats. The monthly plants evapotranspiration obtained in the study was in line with seasonal values obtained in a stormwater retention pond where a FTW was installed $(3.03 \mathrm{~mm}$ day $^{-1}$ during spring, $3.32 \mathrm{~mm}^{\text {day }}{ }^{-1}$ during summer and $1.01 \mathrm{~mm}$ day $^{-1}$ during winter) (Zanin et al., 2018) and in a free water surface constructed wetland ( $3.9 \mathrm{~mm} \mathrm{day}^{-1}$ in spring and summer, $1.3 \mathrm{~mm}$ day $^{-1}$ in autumn and winter) (Dal Ferro et al., 2018) located in the same area. Instead, other studies on wetland herbaceous species cultivated in soil or substrate conditions reported higher cumulative plant evapotranspiration values $(1530.9 \mathrm{~mm}$ : Barco et al., 2018; $3000 \mathrm{~mm}$ : Borin et al., 2011) than that recorded in the current study (on average $290.7 \mathrm{~mm}$ ). The relatively low evapotranspiration rates obtained in this study could be attributed to: i) the newly established vegetation in the FTW system which did not completely colonize the floating modules; and ii) the lack of evaporation from the water surface which was completely covered by the floating modules.

\section{Biometric characteristics}

The biometric characteristics of plant species measured over the monitoring period are reported in Figure 5. C. indica, P. cordata, M. aquatica, T. dealbata and J. effusus had earlier vegetative growth (February) if compared with open-air conditions in the same area (Pavan et al., 2015; Pappalardo et al., 2017), which occurs in mid-March, early April. In particular the relatively high air $\left(15.4^{\circ} \mathrm{C}\right.$ and $20.7^{\circ} \mathrm{C}$ on average in February and March, respectively) and water temperature $\left(15.1^{\circ} \mathrm{C}\right.$ and $16.4^{\circ} \mathrm{C}$ in February and March, respectively) values in the greenhouse, allowed the vegetative cycle to be anticipated by more than one month. For these species, the average shoot height and root length continuously increased from sprouting to harvesting time, reaching the highest average values at the end of the monitoring period (Figure 5). A similar temporal trend over the growing season (sprouting phaseharvesting period) in shoot elongation and root extension was reported for $C$. flaccida (shoot height and root length increased by $30 \mathrm{~cm}$ and $40 \mathrm{~cm}$, respectively), J. effusus (shoot height and root length increased by $40 \mathrm{~cm}$ and $70 \mathrm{~cm}$, respectively) (White and Cousins, 2013) and P. cordata (shoot height and root length increased by $10 \mathrm{~cm}$ and $20 \mathrm{~cm}$, respectively) (Wang et al., 2015).

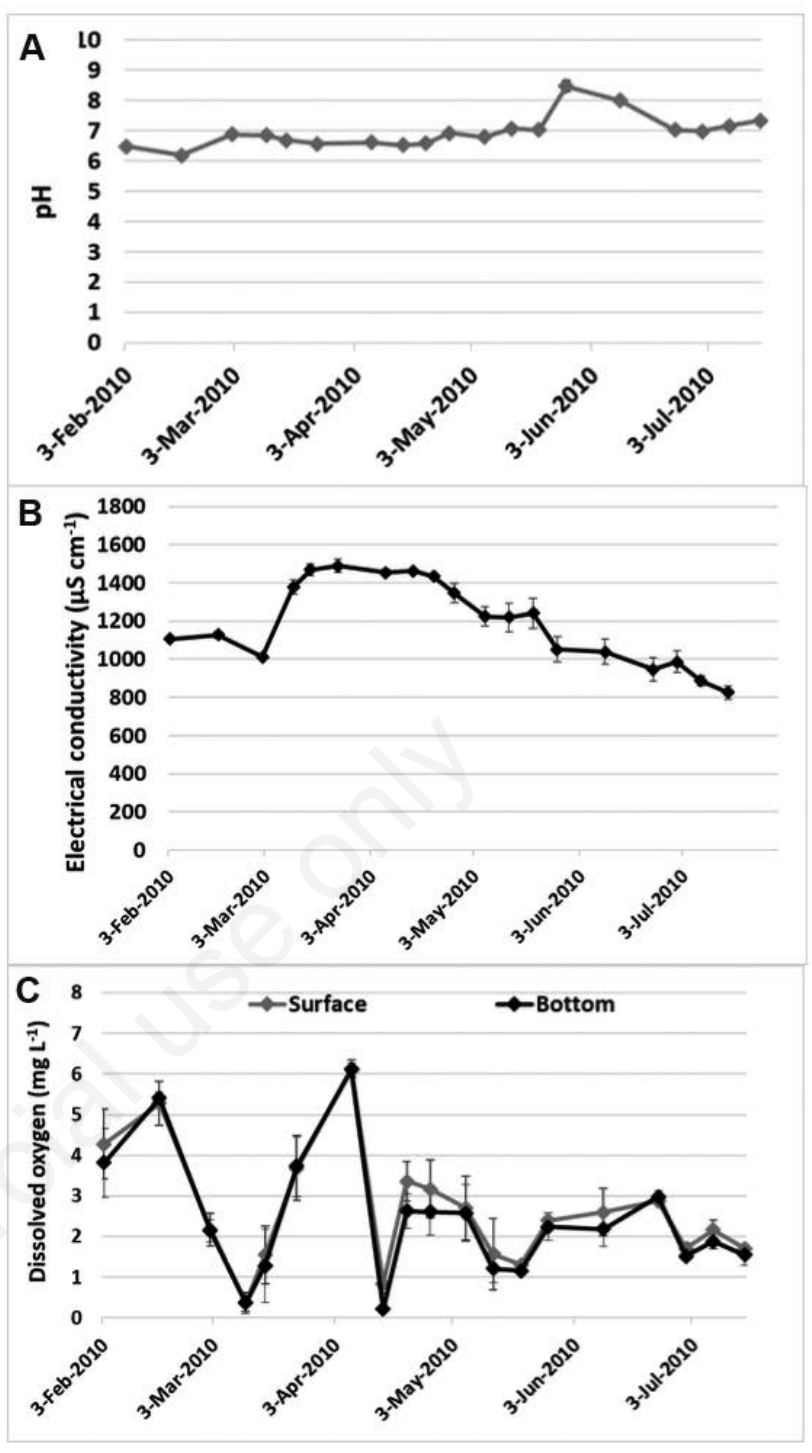

Figure 3. Evolution of A) water $\mathrm{pH}$ (measured at $10 \mathrm{~cm}$ depth), B) electric conductivity $\left(\mu S \mathrm{~cm}^{-1}\right)$ (measured at $10 \mathrm{~cm}$ depth), - water refills and $\Delta$ fertilization treatments $C$ ) dissolved oxygen concentration $\left(\mathrm{mg} \mathrm{L}^{-1}\right)$ (measured at $10 \mathrm{~cm}$ and $50 \mathrm{~cm}$ depth) during the experimental period (average value \pm standard error).

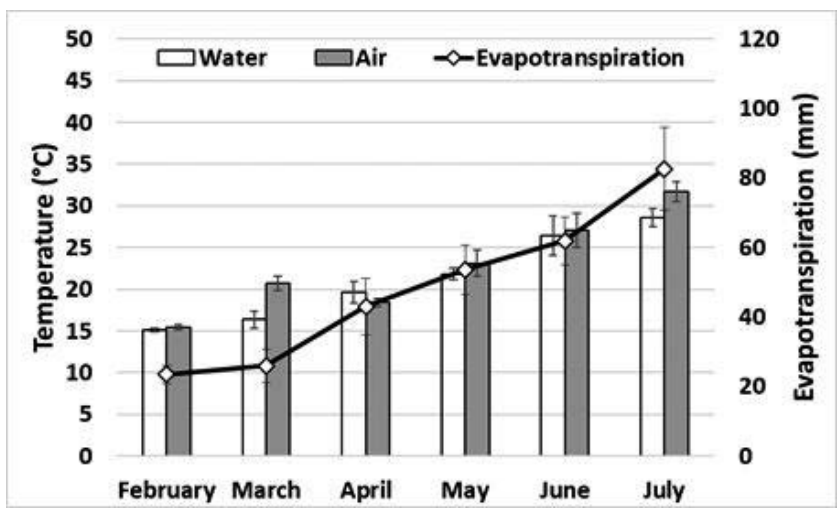

Figure 4. Monthly air and water temperature $\left({ }^{\circ} \mathrm{C}\right)$ and evapotranspiration $(\mathrm{mm})$ values measured in the experimental site (average value \pm standard error). 
Similar to the other species, I. laevigata was characterized by a first phenological phase of shoot elongation (from February until June), with a peak value of $78.2 \pm 10.8 \mathrm{~cm}$ recorded just after blooming ( $3^{\text {rd }}$ June), then by a progressive decreasing of shoot height until the harvesting period with senescence of the plant
(Figure 5). On the contrary, the root length remained almost constant until mid-March and then progressively increased, reaching maximum development just before harvesting $(43.3 \pm 14.5 \mathrm{~cm})$ (Figure 5). The monitoring of biometric characteristics of $O$. javanica, $C$. palustris and $A$. calamus began relatively later with

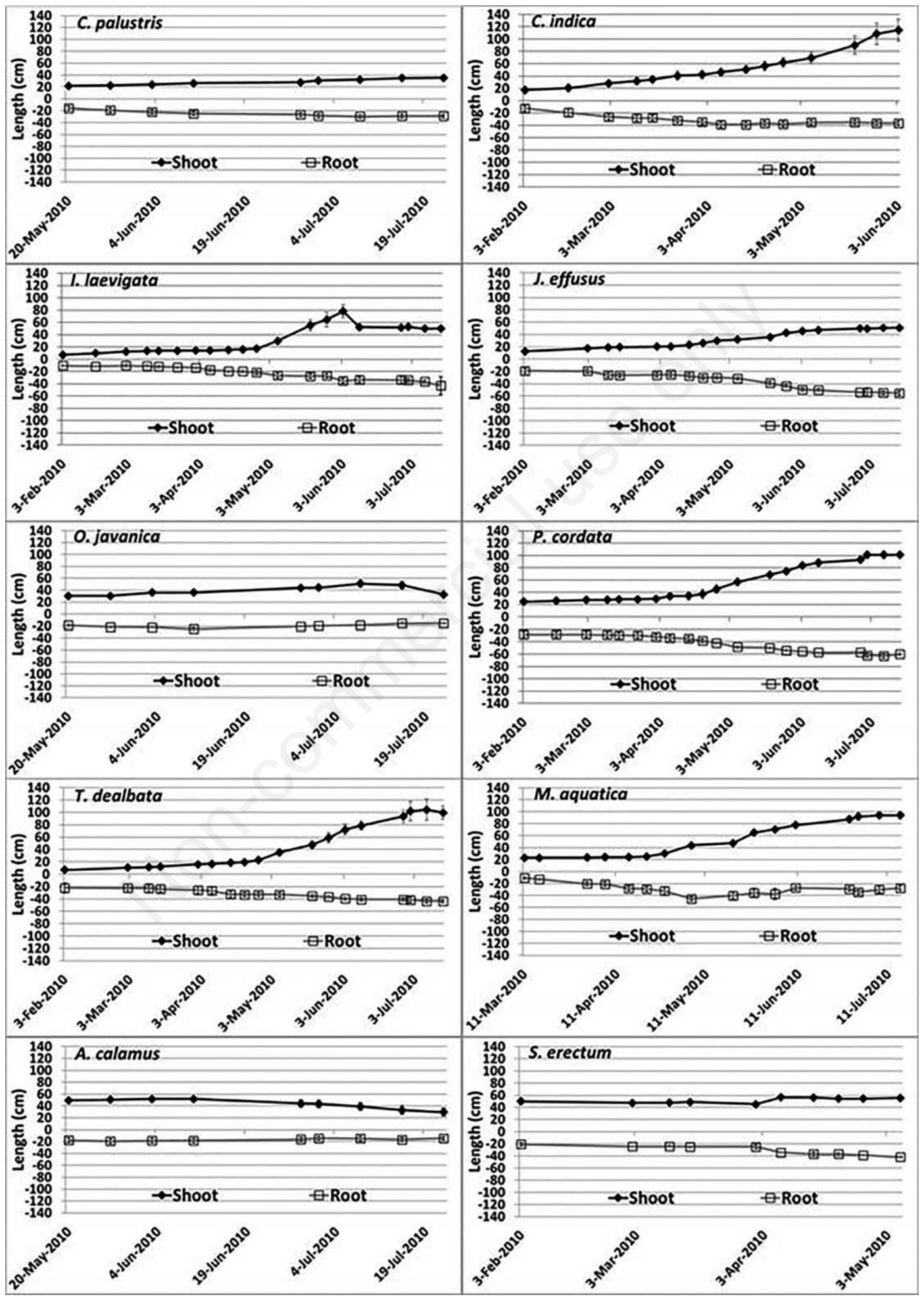

Figure 5. Evolution of the biometric parameters (shoot height, $\mathrm{cm}$ and root length, $\mathrm{cm}$ ) over the growing season for the studied species (average value \pm standard error). 
respect to the other species (at the end of May) (Figure 5). For these species, the sprouting phase was not monitored as they were installed on the floating mats in early spring using plants from a specialist nursery instead of rhizomes. The biometric characteristics of $O$. javanica and C. plaustris remained almost constant over the entire monitoring period with average shoot height of $39.3 \pm 7.8$ $\mathrm{cm}$ and $28.5 \pm 1.7 \mathrm{~cm}$, respectively and average root length of $19.7 \pm 1.0 \mathrm{~cm}$ and $24.9 \pm 1.6 \mathrm{~cm}$, respectively (Figure 5).

A. calamus and $S$. erectum, maintained almost constant shoot height and root length from the beginning of the monitoring period to late spring (May $5^{\text {th }}$ and June $10^{\text {th }}$ for $S$. erectum and $A$. calamus, respectively), they then progressively reduced, reaching the senescence phase before all other species (Figure 5).

Significant differences (ANOVA, $\mathrm{P}<0.01$ ) in the maximum values of both shoot and root length were detected among species due to their different morphology and adaptability to grow in hydroponic conditions (Figure 6). C. indica P. cordata, T. dealbata and $M$. aquatica showed the significantly highest (ANOVA, $\mathrm{P}<0.01$ ) maximum shoot height (average value $103.6 \pm 4.2 \mathrm{~cm}$ ) (Figure 5). On the contrary, C. palustris and J. effusus reached the significantly lowest (ANOVA, $\mathrm{P}<0.01$ ) maximum shoot height with average values of $35.2 \pm 2.7 \mathrm{~cm}$ and $51.0 \pm 2.7 \mathrm{~cm}$, respectively. The maximum shoot height of $J$. effusus was in line with the average values obtained in two FTWs built with Beemat $\AA(43.4 \mathrm{~cm})$ and BioHaven ${ }^{\circledR}(48.7 \mathrm{~cm})$ (Lynch et al., 2015), whereas it was more than twice lower than the maximum value recorded for

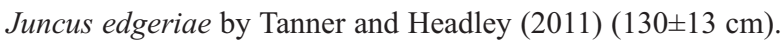

$P$. cordata shoot height was greater than that reported by Wang et al. (2015), treating urban wastewater, with an average value of $43 \mathrm{~cm}$. Shoot height of $A$. calamus matched the values reported by Chang et al. (2010) $(45.2 \mathrm{~cm})$ and Li and Guo (2017) (more than $55 \mathrm{~cm}$ under $9.63 \mathrm{mg} \mathrm{L}^{-1}$ of total nitrogen). The maximum shoot height of $O$. javanica measured in this study was about 2.6 and 2.9 times those obtained in FTWs treating polluted river water and domestic wastewater (Duan et al., 2016).

$P$. cordata and $J$. effusus showed the significantly highest (ANOVA, $\mathrm{P}<0.01)$ maximum root length $(62.0 \pm 3.1 \mathrm{~cm}$ and $51.0 \pm 3.6 \mathrm{~cm}$, respectively), whereas A. calamus and $O$. javanica had the significantly lowest (ANOVA, $\mathrm{P}<0.01)$ ones $(19.5 \pm 3.8 \mathrm{~cm}$ and $24.8 \pm 2.3 \mathrm{~cm}$, respectively). Shorter roots than those recorded in the current study were reported for $J$. effusus $(37.4-39.1 \mathrm{~cm})$ (Lynch et al., 2015) and J. maritimus $(36-38 \mathrm{~cm}$ ) (Pavan et al., 2015). On the contrary, longer roots were obtained in hydroponic conditions by Tanner and Headley (2011) (maximum length for $J$. edgeriae of $87 \pm 12 \mathrm{~cm}$ ) and White and Cousins (2013) (more than $60 \mathrm{~cm}$ for $J$. effusus).

A. calamus root length was in line with values reported by Chang et al. $2010(15.4 \mathrm{~cm})$ and Lai et al. (2011) $(23.0 \mathrm{~cm})$, whereas $C$. indica and $O$. javanica root lengths were respectively 3.4 and 1.7 times those reported by Lai et al. (2011) in a pilot scale plant.

For the majority of studied species, shoot height was positively correlated with root length over the entire monitoring period (Table 3 ), suggesting a simultaneous elongation of all plant organs. Only $S$. erectum and $O$. javanica did not show any significant correlation between these parameters. In addition, the relationship existing between the two parameters followed a species-specific trend during the first part of the vegetative season (sprouting), with a positive linear regression for $C$. indica, $P$. cordata and $T$. dealbata and an insignificant relationship for the other studied species (Table 3). In the next phase, from the beginning of shoot elongation to blooming phase, all studied species behaved similarly, contemporarily increasing shoot height and root expansion in the water column (Table 3). Instead, at flowering-fruit development, it was not possible to find a significant regression between shoot height and root length for the majority of species (Table 3). Indeed, during

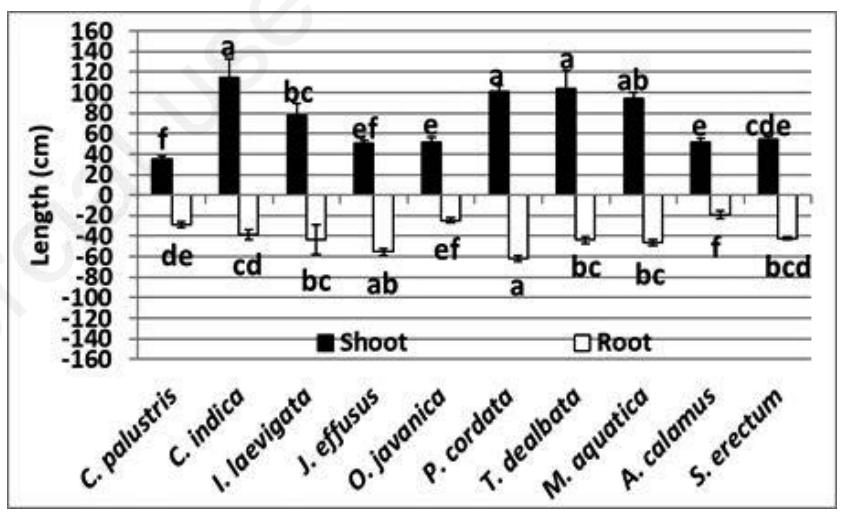

Figure 6. Maximum biometric parameters (shoot height, $\mathrm{cm}$ and root length, $\mathrm{cm}$ ) (average value \pm standard error) for the studied species. Different letters within the same parameter indicate significant differences among the species according to Fischer Least Significant Difference, LSD test, $\mathrm{P}<\mathbf{0 . 0 5}$.

Table 3. Linear regression analysis between root length $(\mathrm{cm}$, dependent variable, $y)$ and shoot height $(\mathrm{cm}$, independent variable, $\mathrm{x})$ for the different phenological phases of used ornamental species.

\begin{tabular}{|c|c|c|c|c|c|c|c|c|}
\hline \multirow[t]{2}{*}{ Spe } & \multicolumn{2}{|c|}{$\begin{array}{c}\text { Sprouting phase } \\
\text { (February } 3^{\text {rd }}-\text { March } 16^{\text {th }} \text { ) }\end{array}$} & \multicolumn{2}{|c|}{$\begin{array}{l}\text { Shoot elongation } \\
\text { (March } 24^{\text {th }} \text {-May } 27^{\text {th }} \text { ) }\end{array}$} & \multicolumn{2}{|c|}{$\begin{array}{l}\text { Flowering-fruit development } \\
\text { (June } 3^{\text {rd }} \text {-July } 30^{\text {th }} \text { ) }\end{array}$} & \multicolumn{2}{|c|}{ Entire cycle } \\
\hline & Equation & $\mathbf{R}$ & Equation & $\mathbf{R}$ & Equation & $\mathbf{R}$ & Equation & $\mathbf{R}$ \\
\hline C. palustris & - & - & $y=-0.9749+0.918 x$ & $+0.48 * * *$ & $y=21.937+0.215 x$ & $+0.19 \mathrm{~ns}$ & $\mathrm{y}=0.608+0.662 \mathrm{x}$ & $+0.50 * * *$ \\
\hline C. indica & $y=5.424+0.665 x$ & $+0.71^{* *}$ & $y=27.356+0.171$ & +0.35 * & $y=22.985+0.118 x$ & $+0.55 \mathrm{~ns}$ & $y=20.608+0.225 x$ & $+0.53 * * *$ \\
\hline I. laevigata & $\mathrm{y}=8.986+0.203 \mathrm{x}$ & $+0.37 *$ & $\mathrm{y}=14.407+0.254 \mathrm{x}$ & $+0.13 * * *$ & $y=108.64-0.697 x$ & $-0.13 n s$ & $\mathrm{y}=12.774+0.590 \mathrm{x}$ & $+0.71 * * *$ \\
\hline J. effusus & $\mathrm{y}=24.610+0.009 \mathrm{x}$ & $+0.01 \mathrm{~ns}$ & $\mathrm{y}=12.151+0.700 \mathrm{x}$ & $+0.69 * * *$ & $\mathrm{y}=34.599+0.337 \mathrm{x}$ & $+0.19 \mathrm{~ns}$ & $y=10.878+0.790 x$ & $+0.80 * *$ \\
\hline O. javanica & - & - & $y=23.033-0.05 x$ & $+0.07 \mathrm{~ns}$ & $y=18.492-0.017 x$ & $-0.070 \mathrm{~ns}$ & $y=23.684-0.093 x$ & $-0.238 \mathrm{~ns}$ \\
\hline P. cordata & $y=15.460+0.511 x$ & +0.51 *** & $\mathrm{y}=22.248+0.398 \mathrm{x}$ & +0.76 *** & $y=53.498+0.455 x$ & $+0.13 \mathrm{~ns}$ & $y=21.331+0.384 x$ & $+0.83 * * *$ \\
\hline T. dealbata & $\mathrm{y}=22.680+0.151 \mathrm{x}$ & $+0.03 \mathrm{~ns}$ & $\mathrm{y}=22.876+0.247 \mathrm{x}$ & $+0.43 * *$ & $\mathrm{y}=43.844-0.280 \mathrm{x}$ & $-0.11 n s$ & $y=25.032+0.157 x$ & $+0.492 * * *$ \\
\hline M. aquatica & $\mathrm{y}=22.686-0.052 \mathrm{x}$ & $+0.05 \mathrm{~ns}$ & $\mathrm{y}=30.034+0.147 \mathrm{x}$ & $+0.20 *$ & $y=22.206+0.130 x$ & $+0.14 \mathrm{~ns}$ & $y=22.817+0.105 x$ & $+0.21 *$ \\
\hline A. calamus & - & - & $\mathrm{y}=-3.293+0.411 \mathrm{x}$ & $+0.36 * *$ & $y=5.049+0.276 x$ & $+0.537 * * *$ & $\mathrm{y}=4.751+0.269 \mathrm{x}$ & $+0.469 * * *$ \\
\hline S. erectum & $\mathrm{y}=23.935-0.002 \mathrm{x}$ & $+0.71 \mathrm{~ns}$ & $y=87.571-0.956 x$ & $-0.66 \mathrm{~ns}$ & - & - & $y=12.104+0.309 x$ & $+0.27 \mathrm{~ns}$ \\
\hline
\end{tabular}

-: not available; ns: not significant; * significant, $\mathrm{P}<0.05$; **: significant, $\mathrm{P}<0.01 ; * * *$ : significant, $\mathrm{P}<0.001$. 
this phenological phase (June-July), plant root systems continued their expansion through the water column, whereas shoot height remained almost constant since the maximum values were reached at the end of June, in correspondence with blooming.

Different root length/shoot height ratio values were found among species (Figure 7). In particular, T. dealbata, J. effusus and I. laevigata $(1.23 \pm 0.11,1.21 \pm 0.06,1.19 \pm 0.09$, respectively) showed the highest values on the average of the vegetative cycle, whereas $S$. erectum, $O$. javanica and $A$. calamus exhibited the lowest ones $(0.54 \pm 0.03,0.56 \pm 0.01,0.41 \pm 0.02$, respectively). Focusing attention on the different vegetative season phases, $C$. indica, $P$. cordata, T. dealbata, M. aquatica and J. effusus progressively reduced their root length/shoot height ratio from the beginning of the growing season (sprouting) to the last phenological phases (Figure 7). The behavior of all other species was different, since their root length/shoot height ratio values were maintained almost constant throughout the monitoring period (Figure 7).

\section{Biomass production}

The studied species gave significantly different (ANOVA, $\mathrm{P}<0.001$ ) biomass production at harvest (Table 4), reflecting the same statistical trend as that observed for shoot height, as testified by the strictly positive correlation existing between plant abovemat biomass production (y) and shoot height $(\mathrm{x})$ : $\mathrm{y}=15.19 \mathrm{x}$ 606.94, $\mathrm{R}^{2}=0.75, \mathrm{P}<0.05$. In particular, $M$. aquatica and $C$. indica showed significantly higher (ANOVA, $\mathrm{P}<0.001$ ) above-mat dry biomass productions than those obtained for $O$. javanica, J. effusus and $C$. palustris, which showed no significant differences (Table 4). M. aquatica gave a much higher production compared to an experiment carried out in mesocosms on LECA substrate (Tamiazzo et al., 2015) under similar climatic conditions and was one of the most productive species in a bioretention pond where Tech-IA ${ }^{\circledR}$ floating mats were installed (Zanin et al., 2018). C. indi$c a$ above-mat production obtained in this study was higher than that reported by Zhang et al. (2007) $\left(0.5-1.0 \mathrm{~kg} \mathrm{~m}^{-2}\right)$ in a pilot scale vertical flow system fed with a simulated nutrient solution, whereas it was in line with results obtained by Zhao et al. (2012) in an FTW treating eutrophic river water (1000-1500 $\mathrm{g} \mathrm{m}^{-2}$ ). Higher above-mat biomass productions than ours were obtained in a pilot FTW treating eutrophic wastewater $\left(2.37-2.43 \mathrm{~kg} \mathrm{~m}^{-2}\right)$, with equal partitioning between stems and leaves (Zhang et al., 2016).

$T$. dealbata and $P$. cordata biomass productions were in dis-

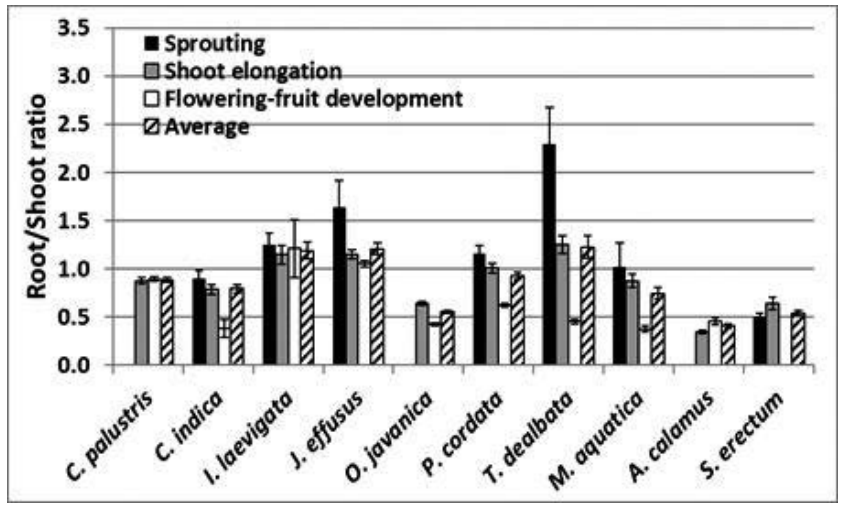

Figure 7. Evolution of the root length/shoot height ratio during the vegetative cycle (average value \pm standard error). agreement with the results found in the scientific literature, since productions of $1989.0 \mathrm{~g} \mathrm{plant}^{-1}$ (T. dealbata) and 10.4-71.8 g plant $^{-1}$ (P. cordata) were reported by Ge et al. (2016), Wang et al. (2014) and Winston et al. (2013), respectively. In the present study, $J$. effusus above-mat production was lower than those harvested by Borin and Salvato (2012) in mesocosm gravel tanks (3210.0 and $5271.0 \mathrm{~g} \mathrm{~m}^{-2}$ ) and by Winston et al. (2013) in an FTW (66.2-106.3 g plant $^{-1}$ ) whereas it was higher than those obtained in a hydroponic culture of stormwater run-off (on average 142.9-188.4 $\mathrm{g} \mathrm{m}^{-2}$ ) (Lynch et al., 2015) and diluted digestate liquid fraction (median value $172.0 \mathrm{~g} \mathrm{~m}^{-2}$ ) (Pavan et al., 2015). S. erectum and A. calamus maximum shoot heights and root lengths were measured until late spring (June), whereas their biomass production was not harvested since they did not survive until the harvesting period (July). The negative adaptability of $S$. erectum contrasted with expectations, since Ennabili et al. (1998) assessed a good growth of the species (1293 $\mathrm{g} \mathrm{m}^{-2}$ and $718 \mathrm{~g} \mathrm{~m}^{-2}$ of above- and below-ground biomass, respectively) in sandy-clay soil typical of coastal wetlands.

\section{$\mathrm{N}$ concentration and uptake}

Despite statistically similar above-mat nitrogen percentage concentrations among species (Table 4), significant differences (ANOVA, $\mathrm{P}<0.001$ ) in their above-mat nitrogen uptakes were detected, mainly depending on above-mat biomass production, as confirmed by Zhu et al. (2011). The similar above-mat nitrogen percentage concentration among the species is probably justified because they were cultivated in the same nutrient solution.

The above-mat $\mathrm{N}$ percentage concentration values observed in this study were lower than those determined in similar experimental conditions for $C$. indica (1.65-2.75\%) (Zhang et al., 2016) but were in line with those reported for $J$. effusus $(0.83 \%$ ) (Lynch et al., 2015), J. edgeriae (1.2\%), C. virgata (1.1\%), C. ustulatus $(1.2 \%)$ and $S$. tabernaemontani (1.4\%) (Tanner and Headley, 2011). Double N concentrations than ours were reported for $C$. indica and $P$. cordata on a floating island treating eutrophic water (Zhao et al., 2012).

Table 4. Above-mat biomass production (average value \pm standard error, $\mathbf{g ~ m}^{-2}$ ), nitrogen percentage concentration (average value \pm standard error, \%), nitrogen uptake (average value \pm standard error, $\mathrm{g} \mathrm{m}^{-2}$ ) and survival rate (\%) of species in the study. Different letters within the same parameter indicate significant differences among the species according to Fischer Least Significant Difference, LSD test $(P<0.001)$.

\begin{tabular}{lcccc} 
Species & $\begin{array}{c}\text { Above-mat } \\
\text { biomass } \\
\left(\mathrm{g} \mathrm{m}^{-2}\right)\end{array}$ & $\begin{array}{c}\text { Nitrogen } \\
\text { concentration } \\
(\%)\end{array}$ & $\begin{array}{c}\text { Nitrogen } \\
\text { uptake } \\
\left(\mathrm{g} \mathrm{m}^{-2}\right)\end{array}$ & $\begin{array}{c}\text { Survivability } \\
(\%)\end{array}$ \\
C. palustris & $33.5 \pm 6.2^{\mathrm{c}}$ & $1.02 \pm 0.006$ & $0.3 \pm 0.06^{\mathrm{c}}$ & 100 \\
C. indica & $1638.9 \pm 359.8^{\mathrm{b}}$ & $0.98 \pm 0.046$ & $15.1 \pm 2.54^{\mathrm{b}}$ & 100 \\
\hline I. laevigata & $104.1 \pm 4.6^{\mathrm{c}}$ & $1.02 \pm 0.004$ & $1.1 \pm 0.04^{\mathrm{c}}$ & 100 \\
J. effusus & $88.8 \pm 22.1^{\mathrm{c}}$ & $1.01 \pm 0.012$ & $0.9 \pm 0.23^{\mathrm{c}}$ & 66.7 \\
\hline O. javanica & $102.3 \pm 3.4^{\mathrm{c}}$ & $1.01 \pm 0.012$ & $1.0 \pm 0.04^{\mathrm{c}}$ & 100 \\
P. cordata & $483.4 \pm 132.1^{\mathrm{c}}$ & $1.02 \pm 0.010$ & $5.0 \pm 1.39^{\mathrm{c}}$ & 100 \\
\hline T. dealbata & $566.1 \pm 200.1^{\mathrm{c}}$ & $1.00 \pm 0.007$ & $5.7 \pm 2.00^{\mathrm{c}}$ & 100 \\
M. aquatica & $3162.1 \pm 512.0^{\mathrm{a}}$ & $1.02 \pm 0.003$ & $32.1 \pm 5.29^{\mathrm{a}}$ & 50 \\
\hline A. calamus & - & - & - & 0 \\
S. erectum & - & - & - & 0 \\
\hline Z. aetiopica & - & - & - & 0 \\
Sig. & $* * *$ & $\mathrm{~ns}$ & $* * *$ & -
\end{tabular}

-: not available, ns: not significant, ${ }^{* *}$ : significant at $\mathrm{P}<0.001$. 
$M$. aquatica and $C$. indica showed significantly higher (ANOVA, $\mathrm{P}<0.01$ ) above-mat nitrogen uptakes than those of all the other species, which in turn did not significantly differ (Table 4). C. indica above-mat $\mathrm{N}$ uptake was in line with results reported for C. flaccida (16.1 $\mathrm{g} \mathrm{N} \mathrm{m}^{-2}$ ) by White and Cousins (2013). Despite White and Cousins (2013) reporting good N uptake for $J$. effusus (28.5 $\left.\mathrm{g} \mathrm{m}^{-2}\right)$, a contrasting behavior was observed in this study since the average $\mathrm{N}$ uptake was $0.9 \mathrm{~g} \mathrm{~m}^{-2}$.

The above-mat $\mathrm{N}$ uptake through plants aerial biomass harvesting plays an important role in wastewater treatment, because it allows a definitive removal of the element from the treatment site.

At this purpose, the harvesting of vegetation in a FTW should be done before plant complete senescence to limit the translocation of nutrients from above-mat to below-mat tissues, therefore maximizing nutrients removal from wastewater. In addition, plant biomass should be cut almost $10 \mathrm{~cm}$ above the floating mat to guarantee an enough coverage and protection of the blow-mat tissues against cold icy winter, therefore allowing an excellent vegetative regrowth.

\section{Survival rates}

All plants of C. indica, I. laevigata, O. javanica, P. cordata, $C$. palustris and $T$. dealbata survived for the entire growing season (Table 4). These findings agree with Wu et al. (2011), Zhu et al. (2011) and Ge et al. (2016) who observed high survival rates for $T$. dealbata, O. javanica and C. indica, respectively. Also, Xu et al. (2017) reported an interesting adaptability of $T$. dealbata under hydroponic conditions, with survival rates higher than $98 \%$. The high survival of $C$. indica was in opposition to that obtained in a pilot scale experiment where the species was cultivated in open-air conditions, and managed with high water and nutrient inputs (Barco et al., 2018; Maucieri et al., 2018) because it was not able to tolerate winter cold. The high survival exhibited by $C$. palustris was previously confirmed by Pappalardo et al. (2017) in an FTW treating agricultural run-off ( $73 \%$ survival rate). The excellent survival of Iris was previously confirmed by Barco and Borin (2017), Pavan et al. (2015) and Mietto et al. (2013). The good performances recorded in the current study for $P$. cordata disagreed with results obtained in a stormwater retention pond where the species mortality varied between $68 \%$ and $89 \%$ (Tharp et al., 2019).

Table 5. Suitability index calculated for all studied species.

\begin{tabular}{lcccccc} 
Species & $\begin{array}{c}\text { Survival } \\
\text { rate }\end{array}$ & $\begin{array}{c}\text { Above-mat } \\
\text { biomass }\end{array}$ & $\begin{array}{c}\text { Nitrogen } \\
\text { uptake }\end{array}$ & $\begin{array}{c}\text { Root } \\
\text { length }\end{array}$ & $\begin{array}{c}\text { Root/Shoot } \\
\text { ratio }\end{array}$ & $\begin{array}{c}\text { Suitability } \\
\text { index }\end{array}$ \\
C. palustris & 2 & 1 & 1 & 2 & 3 & 14 \\
C. indica & 2 & 2 & 2 & 2 & 2 & 16 \\
\hline I. laevigata & 2 & 1 & 1 & 3 & 3 & 16 \\
J. effusus & 1 & 1 & 1 & 3 & 3 & 8 \\
\hline O. javanica & 2 & 1 & 1 & 2 & 2 & 12 \\
P. cordata & 2 & 1 & 1 & 3 & 3 & 16 \\
\hline T. dealbata & 2 & 1 & 1 & 3 & 3 & 16 \\
M. aquatica & 1 & 3 & 3 & 3 & 2 & 11 \\
\hline A. calamus & 0 & - & - & 1 & 1 & 0 \\
S. erectum & 0 & - & - & 3 & 2 & 0 \\
\hline Z. aetiopica & 0 & - & - & - & - & 0 \\
\hline
\end{tabular}

Negative performances were obtained for A. calamus, $Z$. aetiopica and $S$. erectum which did not survive the growing season. The low adaptability of $S$. erectum to hydroponic conditions was also observed by Pappalardo et al. (2017) with only $8 \%$ of plants surviving after the first growing season.

\section{Suitability index}

As mentioned earlier, the SI was adopted to select the most promising species to install in FTWs, basing on different characteristics. Considering this approach, $C$. indica, P. cordata, T. dealbata and I. laevigata were the most suitable species to install in an FTW (SI was 16) thanks to their high survivability, high biomass production as well as nitrogen uptake and a comparable extension of aerial and root tissues (Table 5). Despite J. effusus and C. palustris showed a balanced development between aerial and root tissues, their above-mat biomass production and consequent nitrogen uptake were lower than those obtained for the previous species, therefore justifying intermediate SI values (from 8 to 14) (Table 5). An intermediate SI was also obtained for $O$. javanica, whose installation in FTW should be limited due to the higher extension of aerial than root tissues therefore indicating probable overturning of floating vegetated barriers under extreme meteorological events. The choice of $Z$. aetiopica, $S$. erecutum and A. calamus should be avoided due to a scarce aptitude to survive under hydroponic conditions.

\section{Conclusions}

The study aimed to report the growth performances of eleven un-floating ornamental species installed in a pilot scale FTW and fertilized with a synthetic nutrient solution. In addition, it would give practical advice for the installation of FTWs, especially in urban water bodies where the necessity to select plant species characterized by contemporaneous adaptability to survive under high pollutants load and esthetic-ornamental values represents a real difficulty to be overcome. For this purpose, $C$. indica, $P$. cordata and $T$. dealbata appeared to be the most suitable species, thanks to their vigor during the vegetative season, the highest above-mat biomass produced as well as nitrogen uptake, excellent survivability and balanced growth between aerial and root tissues. Excellent growth was also shown by $M$. aquatica, even though it did not completely survive like the previous species. The selection of $O$. javanica should be avoided due to the higher development of above-mat rather than below-mat tissues with a consequent probable overturning of the floating barriers under extreme meteorological events.

The negative performances exhibited by Z. aetiopica, S. erectum and A. calamus in terms of survival does not suggest their installation in hydroponic conditions.

\section{References}

APHA, 1998. Standard Methods for the Examination of Water and Wastewater, 20th edn. American Public Health Association, American Water Works Association, and Water Environment Federation, Washington, DC.

Ayers RS, Westcot DW, 1999. Water Quality for Agriculture. Irrigation and Drainage Paper. FAO Irrigation and Drainage Paper 29, Rev. 1. FAO, Rome, p. 174. 
Barco A, Borin M, 2017. Treatment performance and macrophytes growth in a restored hybrid constructed wetland for municipal wastewater treatment. Ecol. Eng. 107:160-71.

Barco A, Maucieri C, Borin M, 2018. Root system characterization and water requirements of ten perennial herbaceous biomass species for biomass production managed with high nitrogen and water inputs. Agr. Water Manage. 196:37-47.

Bi R, Zhou C, Jia Y, Wang S, Li P, Reichwaldt ES, Liu W., 2019. Giving waterbodies the treatment they need: A critical review of the application of constructed floating wetlands. J. Environ. Manage. 238:484-98.

Borin M, Milani M, Salvato M, Toscano A, 2011. Evaluation of Phragmites australis (Cav.) Trin. evapotranspiration in Northern and Southern Italy. Ecol. Eng. 37:721-8.

Borin M, Salvato M, 2012. Effects of five macrophytes on nitrogen remediation and mass balance in wetland mesocosms. Ecol. Eng. 46:34-42.

Borne KE, 2014. Floating treatment wetland influences on the fate and removal performance of phosphorus in stormwater retention ponds. Ecol. Eng. 69:76-82.

Borne KE, Fassman-Beck EA, Tanner CC, 2014. Floating treatment wetland retrofit to improve stormwater pond performance for suspended solids, copper and zinc. Ecol. Eng. 54:173-82.

Bortolini L, Maucieri C, Borin M, 2018. A tool for the evaluation of irrigation water quality in the arid and semi-arid regions. Agron. J. 8:23.

Chanc LMG, Van Brunt SC, Majsztrik JC, White S.A., 2019. Shortand long-term dynamics of nutrient removal in floating treatment wetlands. Water Res. 159:153-63.

Chang J, Liu D, Cao H, Chang SX, Wang X, Huang C, Ge Y, 2010. $\mathrm{NO}_{3}{ }^{-} / \mathrm{NH}_{4}{ }^{+}$ratios affect the growth and $\mathrm{N}$ removal ability of Acorus calamus and Iris pseudacorus in a hydroponic system. Aquat. Bot. 93:216-20.

Chang NB, Xuan Z, Marimon Z, Islam K, Wanielista MP, 2013. Exploring hydrobiogeochemical processes of floating treatment wetlands in a subtropical stormwater wet detention pond. Ecol. Eng. 54:66-76.

Chen Z, Cuervo DP, Müller JA, Wiessner A, Köser H, Vymazal J, Kästner M, Kuschk P, 2016. Hydroponic root mats for wastewater treatment - a review. Environ. Sci. Pollut. R. 23:15911-28.

Chua LHC, Tan SBK, Sim CH, Goyal MK, 2012. Treatment of baseflow from an urban catchment by a floating wetland system. Ecol. Eng. 49:170-80.

Dal Ferro N, Ibrahim HMS, Borin M, 2018. Newly-established free water surface constructed wetland to treat agricultural waters in the low-lying Venetian plain: performance on nitrogen and phosphorus removal. Sci. Total Environ. 639:852-9.

De Stefani G, Tocchetto D, Salvato M, Borin M, 2011. Performance of a floating treatment wetland for in-stream water amelioration in NE Italy. Hydrobiologia 674:157-67.

Duan J, Feng Y, Yu Y, He S, Xue L, Yang L, 2016. Differences in the treatment efficiency of a cold-resistant floating bed plant receiving two types of low-pollution wastewater. Environ. Monit. Assess. 188:283.

Ennabili A, Ater M, Radoux M, 1998. Biomass production and NPK retention in macrophytes from wetlands of the Tingitan Peninsula. Aquat. Bot. 62:45-56.

FAO, 2011. Quality assurance for animal feed analysis laboratories. FAO Animal Production and Health Manual no. 14. Rome.

Faulwetter JL, Burr MD, Cunningham AB, Stewart FM, Camper AK, Stein OR, 2011. Floating treatment wetlands for domestic wastewater treatment. Water Sci. Technol. 64:2089-95.

Gao L, Zhou W, Wu S, He S, Huang J, Huang J, Zhang X, 2018.
Nitrogen removal by thiosulfate-driven denitrification and plant uptake in enhanced floating treatment wetland. Sci. Total Environ. 621:1550-8.

Ge Z, Feng C, Wang X, Zhang J 2016. Seasonal applicability of three vegetation constructed floating treatment wetlands for nutrient removal and harvesting strategy in urban stormwater retention ponds. Int. Biodeter. Biodegr. 112:80-7.

Geng Y, Han W, Yu C, Jiang Q, Wu J, Chang J, Ge Y, 2017. Effect of plant diversity on phosphorus removal in hydroponicmicrocosms simulating floating constructed wetlands. Ecol. Eng. 107:110-9.

Hartshorn N, Marimon Z, Xuan Z, Cormier J, Chang NB, Wanielista M, 2016. Complex interactions among nutrients, chlorophyll-a, and microcystins in three stormwater wet detention basins with floating treatment wetlands. Chemosphere 144:408-19.

Headley TR, Tanner CC, 2006. Application of floating wetlands for enhanced stormwater treatment: a review. NIWA Client Report HAM2006-123 for Auckland Regional Council, ARC Technical Publication No 324. (TP324, November 2006).

$\mathrm{Hu}$ MH, Yuan JH, Yang XE, He ZL, 2010. Effects of temperature on purification of eutrophic water by floating eco-island system. Acta Ecol. Sin. 30:310-8.

Ibrahim HMS, Barco A, Borin M, 2017. Plant species used in floating treatments wetlands: A decade of experiments in North Italy. $7^{\text {th }}$ European Pond Conservation Network Workshop + LIFE CHARCOS Seminar and $12^{\text {th }}$ Annual SWS European Chapter Meeting - Abstract book. 171-2.

Keizer-Vlek HE, Verdonschot PF, Verdonschot RC, Dekkers D, 2014. The contribution of plant uptake to nutrient removal by floating treatment wetlands. Ecol. Eng. 73:684-90.

Ladislas S, Gérente C, Chazarenc F, Brisson J, Andrès Y, 2015. Floating treatment wetlands for heavy metal removal in highway stormwater ponds. Ecol. Eng. 80:85-91.

Ladislas S, Gerente C, Chazarenc F, Brisson J, Andres Y, 2013. Performances of two macrophytes species in floating treatment wetlands for cadmium, nickel, and zinc removal from urban stormwater runoff. Water Air Soil Poll. 224:1408.

Lai WL, Wang SQ, Peng CL, Chen ZH, 2011. Root features related to plant growth and nutrient removal of 35 wetland plants. Water Res. 45:3941-50.

Li X, Guo R, 2017. Comparison of nitrogen removal in floating treatment wetlands constructed with Phragmites australis and Acorus calamus in a cold temperate zone. Water Air Soil Poll. 228:132.

Lu HL, Ku CR, Chang YH, 2015. Water quality improvement with artificial floating islands. Ecol. Eng. 74:371-5.

Lynch J, Fox LJ, Owen Jr JS, Sample DJ, 2015. Evaluation of commercial floating treatment wetland technologies for nutrient remediation of stormwater. Ecol. Eng. 75:61-9.

Maucieri C, Florio G Borin M, 2018. Ligneous-cellulosic, nitrophilous and wetland plants for biomass production and watertable protection against nutrient leaching. Eur. J. Agron. 96:77-86.

McAndrew B, Ahn C, 2017. Developing an ecosystem model of a floating wetland for water quality improvement on a stormwater pond. J. Environ. Manage. 202:198-207.

McAndrew B, Ahn C, Spooner J, 2016. Nitrogen and sediment capture of a floating treatment wetland on an urban stormwater retention pond - The case of the Rain Project. SustainabilityBasel 8:972.

Mietto A, Borin M, Salvato M, Ronco P, Tadiello N, 2013. Tech-IA floating system introduced in urban wastewater treatment plants in the Veneto region-Italy. Water Sci. Technol. 68:1144-50. 
Olguín EJ, Sánchez-Galván G, Melo FJ, Hernández VJ, GonzálezPortela RE, 2017. Long-term assessment at field scale of Floating Treatment Wetlands for improvement of water quality and provision of ecosystem services in a eutrophic urban pond. Sci. Total Environ. 584:561-71.

Pappalardo SE, Ibrahim HMS, Cerinato S, Borin M, 2017. Assessing the water-purification service in an integrated agricultural wetland within the Venetian Lagoon drainage system. Mar. Freshwater Res. 68:2205-15.

Pavan F, Breschigliaro S, Borin M, 2015. Screening of eighteen species for digestate phytodepuration. Environ. Sci. Pollut. R. 22:2455-66.

Pavlineri N, Skoulikidis NT, Tsihrintzis VA, 2017. Constructed floating wetlands: a review of research, design, operation and management aspects, and data meta-analysis. Chem. Eng. J. 308:1120-32.

Quing W, Yue H, Shuqun L, Sen P, Huabing Z, 2016. Microbial mechanisms of using enhanced ecological floating beds for eutrophic water improvement. Bioresource Technol. 211:451-6.

Rehman K, Ijaz A, Arslan M, Afzal M, 2019. Floating treatment wetlands as biological buoyant filters for wastewater reclamation. Int. J. Phytoremediat. 1-17.

Saeed T, Paul B, Afrin R, Al-Muyeed A, Sun G, 2016. Floating constructed wetland for the treatment of polluted river water: A pilot scale study on seasonal variation and shock load. Chem. Eng. J. 287:62-73.

Sanicola O, Lucke T, Stewart M, Tondera K, Walker C, 2019. Root and shoot biomass growth of constructed floating wetlands plants in saline environments. Int. J. Env. Res. Pub. He. 16:275.

Shahid MJ, Arslan M, Siddique M, Ali S, Tahseen R, Afzal M, 2019. Potentialities of floating wetlands for the treatment of polluted water of river Ravi, Pakistan. Ecol. Eng. 133:167-76.

Silvestri N, Giannini V, Dragoni F, Bonari E, 2017. A multi-adaptive framework for the crop choice in paludicultural cropping systems. Ital. J. Agron. 12:69-76.

Spangler JT, Sample DJ, Fox LJ, Owen Jr JS, White SA, 2019a. Floating treatment wetland aided nutrient removal from agricultural runoff using two wetland species. Ecol. Eng. 127: 468-479.

Spangler JT, Sample DJ, Fox LJ, Albano JP, White SA, 2019b. Assessing nitrogen and phosphorus removal potential of five plant species in floating treatment wetlands receiving simulated nursery runoff. Environ. Sci. Pollut. R. 26:5751-68.

Tamiazzo J., Breschigliaro S., Salvato M., Borin M., 2015. Performance of a wall cascade constructed wetland treating surfactants polluted water. Environ. Sci. Pollut. Res. 22:12816-28.

Tanner CC, Headley TR, 2011. Components of floating emergent macrophyte treatment wetlands influencing removal of stormwater pollutants. Ecol. Eng. 37:474-86.

Tharp R, Westhelle K, Hurley S, 2019. Macrophyte performance in floating treatment wetlands on a suburban stormwater pond: Implications for cold climate conditions. Ecol. Eng. 136:152-9.

Urakawa H, Dettmar DL, Thomas S, 2017. The uniqueness and biogeochemical cycling of plant root microbial communities in a floating treatment wetland. Ecol. Eng. 108:573-80.

Van de Moortel AMK, Meers E, De Pauw N, Tack FMG, 2010. Effects of vegetation, season and temperature on the removal of pollutants in experimental floating treatment wetlands. Water Air Soil Pollut. 212:281-97.

Vymazal J, Krőpfelová L, 2008. Wastewater treatment in construct- ed wetlands with horizontal sub-surface flow. Springer, Dordrecht.

Wang WH, Wang Y, Li Z, Wei CZ, Zhao JC, Sun LQ, 2017. Effect of a strengthened ecological floating bed on the purification of urban landscape water supplied with reclaimed water. Sci. Total Environ. 622:1630-9.

Wang CY, Sample DJ, Bell C, 2014. Vegetation effects on floating treatment wetland nutrient removal and harvesting strategies in urban stormwater ponds. Sci. Total Environ. 499:384-93.

Wang CY, Sample DJ, Day SD, Grizzard TJ, 2015. Floating treatment wetland nutrient removal through vegetation harvest and observations from a field study. Ecol. Eng. 78:15-26.

West M, Fenner N, Gough R, Freeman C, 2017. Evaluation of algal bloom mitigation and nutrient removal in floating constructed wetlands with different macrophyte species. Ecol. Eng. 108:581-8.

White SA, Cousins MM, 2013. Floating treatment wetland aided remediation of nitrogen and phosphorus from simulated stormwater runoff. Ecol. Eng. 61:207-15.

Winston RJ, Hunt WF, Kennedy SG, Merriman LS, Chandler J, Brown D, 2013. Evaluation of floating treatment wetlands as retrofits to existing stormwater retention ponds. Ecol. Eng. 54:254-65.

Wu JQ, Wang M, Wu J, Jiang Y, Sun CJ, Cao Y, 2011. Study on the nitrogen and phosphorus uptake ability of four plants cultivated on floating-bed. Zhongguo huanjing kexue 32:995-9.

Vymazal J, 2013. Emergent plants used in free water surface constructed wetlands: a review. Ecol. Eng. 61P:582-92.

Xu B, Wang X, Liu J, Wu J, Zhao Y, Cao W, 2017. Improving urban stormwater runoff quality by nutrient removal through floating treatment wetland and vegetation harvest. Sci. Rep.-UK 7:7000.

Zanin G, Bortolini L, Borin M, 2018. Assessing stormwater nutrient and heavy metal plant uptake in an experimental bioretention pond. Land 7:150.

Zhang CB, Liu WL, Pan XC, Guan M, Liu SY, Ge Y, Chang J, 2014. Comparison of effects of plant and biofilm bacterial community parameters on removal performances of pollutants in floating island systems. Ecol. Eng. 73:58-63.

Zhang L, Zhao J, Cui N, Dai Y, Kong L, Wu J, Cheng S, 2016. Enhancing the water purification efficiency of a floating treatment wetland using a biofilm carrier. Environ. Sci. Pollut. R. 23:7437-43.

Zhang Z, Rengel Z, Meney K, 2007. Nutrient removal from simulated wastewater using Canna indica and Schoenoplectus validus in mono-and mixed-culture in wetland microcosms. Water Air Soil Pollut. 183:95-105.

Zhang L, Sun Z, Xie J, Wu J, Cheng S, 2018. Nutrient removal, biomass accumulation and nitrogen-transformation functional gene response to different nitrogen forms in enhanced floating treatment wetlands. Ecol. Eng. 112:21-5.

Zhao F, Xi S, Yang X, Yang W, Li J, Gu B, He Z, 2012. Purifying eutrophic river waters with integrated floating island systems. Ecol. Eng. 40:53-60.

Zhou X, Wang G, 2010. Nutrient concentration variations during Oenanthe javanica growth and decay in the ecological floating bed system. J. Environ. Sci. 22:1710-7.

Zhu L, Li Z, Ketola T, 2011. Biomass accumulations and nutrient uptake of plants cultivated on artificial floating beds in China's rural area. Ecol. Eng. 37:1460-6. 